\title{
MELIA AZEDARACH L. FRUIT EXTRACT AS A POTENTIAL CANDIDATE IN CONTROLLING THE NEURAESCHNA HAGEN, 1867 (ODONATA: AESHNIDAE), PREDOMINANT PREDATORS FOR FISH FINGERLINGS
}

\author{
TOMAZELLI, JR., O.'; SOUZA-FRANCO, G.M.2; MUNARINI, A. ${ }^{2}$; CASACA, J.M. ${ }^{1}$; NIERO, R. ${ }^{3}$; \\ MONACHE, F.D. ${ }^{3} \&$ DAL MAGRO, J. ${ }^{2 *}$ \\ 1. Empresa de Pesquisa Agropecuária e Extensão Rural de Santa Catarina - EPAGRI/Cepaf, \\ Chapecó, SC, Brazil. \\ 2. Programa de Pós-graduação em Ciências Ambientais (PPGCA) da Universidade Comunitária da \\ Região de Chapecó, Chapecó, SC, Brazil. \\ 3. Programa de Pós-Graduação em Ciências Farmacêuticas e Núcleo de Investigações Químico-Far- \\ macêuticas (NIQFAR)-Universidade do Vale do Itajaí, Itajaí, SC, Brazil \\ *Corresponding author: jaci@unochapeco.edu.br
}

\begin{abstract}
Tomazelli, O.Jr.; Franco, G.M.S.; Munarini, A.; Casaca, J.M; Niero, R.; Monache, F.D. \& Magro, J.D., (2016). Melia azedarach $L$. fruit extract as a potential candidate in controlling the neuraeschna Hagen, 1867 (odonata: aeshnidae), predominant predators for fish fingerlings. Braz. J. Aquat. Sci. Technol. 20(1). eISSN 1983-9057. DOI: 10.14210/ bjast.v20n1. Odonata larvae in fishponds prey on fish fingerlings and decrease the profits from production. With the goal of eliminating these larvae from fishponds, large quantities of pesticides are applied. These products are toxic to fish and have unpredictable effects on the food chain. The objective of this study is to evaluate the effect of the plant extract of fruits of Melia azedarach (CEE) and of methyl parathion (MP) adsorbed in silica in the control of Neuraeschna larvae (Odonata: Aeshnidae). The $\mathrm{LC}_{50-18 \mathrm{~h}}$ for CEE was $0.57 \mathrm{mg} \mathrm{L}^{-1}$, and for MP the $\mathrm{LC}_{50-12 \mathrm{~h}}$ was $0.17 \mathrm{mg} \mathrm{L}^{-1}$. Two compounds with the highest concentration were isolated and identified from CEE, linoleic acid and melianone. The latter is a triterpene precursor of limonoids, compounds with insecticide properties. The substitution of synthetic pesticides for natural products is a path towards the sustainability of fish farming.
\end{abstract}

Keywords: Plant extracts, Neuraeschna, Chinaberry, Fish farming, Melia azedarach.

\section{INTRODUCTION}

With the development of fish farming in Brazil, problems emerged that reached critical levels, among which we can highlight the predation of fingerlings by adults and larvae of aquatic insects. The highly predatory habit of these larvae has constituted a problem not only in Brazil but also in other countries (Santos et al., 1998). In fishponds, this is one of the factors that contributes to the reduction of the survival of the fingerlings and consequently to the decrease of production profits (Zaniboni Filho, 2000).

In the cultivation of aquatic organisms, as in every food production sector, chemical products are inputs that are largely used to benefit production. They range from relatively simple, as in extensive systems that can be limited by the use of chemical and organic fertilizers, to the most complex, semi- and super-intensive types, where a variety of natural and synthetic products are used (Rohana et al., 1996).

The use of organophosphate insecticides and other pesticides with the objective of controlling odonata larvae and the main zooplankton groups that are predators of post-larval fish in Brazil dates back to the beginning of the 1980s (Garadi et al., 1988).
In Europe, such compounds had already been used for fifteen years to prepare fishponds for fish farming (Woynarovich \& Horváth, 1981; Garadi et al., 1988). In Brazil, the efficiency of trichlorfon and methyl parathion to combat odonatas has been evaluated by Garadi et al. (1988). Although this type of control is efficient, it is prohibited in many countries because it causes water contamination and death of part of the zooplankton necessary as food for post-larval fish and fingerlings (Zaniboni Filho, 2000). Currently, synthetic pesticides continue to be used for these purposes and the control of ectoparasites in fishponds (Tamassia, 1996; Cruz, 2005; Santos, 2007). In recreational fishing areas, they are also consistently used, which may lead to various problems, as they are dangerous and resistant products whose degradation products in the environment may be just as or more deleterious to the organisms than the original product form (Eler et al., 2006).

The use of chemical products such as insecticides and bactericides in culture tanks may have a cumulative effect and represent a risk to food security and to the environment (Boyd \& Massaut, 1999). Application of these insecticides may result in high levels of residues in the fish, including at the time of eating, as the grace periods for these chemicals are 
Tomazelli, O.Jr., et al. (2016). Control of fingerlings predators by herbal extract.

typically not respected by the fish farmers (Rodrigues et al., 1997). Santos (2007) detected an accumulation in fish fillets subjected to diflubenzuron and methyl parathion with values that exceeded the maximum limits recommended for food according to the Codex Alimentarius.

The availability of natural products for use in aquaculture in substitution of synthetic products to control pests and diseases opens up new frontiers for study. These products are rich in a variety of nutrients and serve as a repository of new additives for food for aquatic animals. Research has show the use of natural products to increase the digestibility of nutrients, improve food conversion, increase weight gain, control parasites, as immunostimulants, antiviral and antibacterial activity (Ghosh et al., 2014; Chakraborty and Ghosh, 2014; Xiang \& Zhou, 2000; Ardó et al., 2008; Abutbul et al., 2005). Other studies have shown the use of natural products with the use of Aloe vera L. in water transport to control the stress in Matrinchã, Brycon amazonicus (Zanuzzo, 2010), in the control of monogenetics in Astronotus ocellatus, among young tambaqui Colossoma macropomum (Claudiano et al., 2009), and in the control of white spot virus in Penaeus monodon (Balasubramanian et al., 2007; Balasubramanian et al., 2008).

These studies open up an extensive field of phytochemical study on the identification of chemical groups and the identification and isolation of biologically active molecules for use in aquaculture. Based on this emerging field, the objective of this work is to evaluate the effect of chinaberry, Melia azedarach L., vegetable extract in the control of odonata larvae that are predators of young fish and to compare its effects with those of a traditionally used insecticide.

\section{MATERIAL AND METHODS}

\section{Plant material}

Chinaberry (Melia azedarach, L., 1753) is a tree belonging to the Meliaceae family. It is popularly known as chinaberry, chinaberry tree, Persian lilac, white cedar, and pride-of-India, among others (Jain et al., 2015). Originating in Southeast Asia, this species is a short-lived, deciduous tree with a height of $6-15 \mathrm{~m}$ and a trunk that is $30-60 \mathrm{~cm}$ in diameter. It has drupe type fruits, which are semi-rounded with a smooth pericarp that is slightly transparent. The fruits become yellow when they are ripe, are around $15 \mathrm{~mm}$ in diameter, yellow, and initially smooth but turn rough. They bloom in the Brazilian spring during the months of September, October, and November (Schneider, 1987).

\section{Preparation of plant extract}

The chinaberry fruits were collected on a rural property located in the municipality of Guatambu, SC, with coordinates of $27^{\circ} 06^{\prime} 34.24^{\prime \prime} S$ and $52^{\circ} 42^{\prime} 39.65^{\prime \prime}$ $\mathrm{W}$. Then, the fruits were weighed (total mass of 1.34 $\mathrm{kg}$ ), dried at a temperature of $40^{\circ} \mathrm{C}$, and ground with ethanol for seven days in a percolator. After this period, the ground up samples were filtered, collected, and concentrated in a rotary evaporator under reduced pressure at a temperature of $40^{\circ} \mathrm{C}$, obtaining $57.67 \mathrm{~g}$ of crude chinaberry ethanolic extract (CEE).

\section{Adsorption of plant extract from chinaberry and methyl parathion in silica gel}

To perform the biological tests, both the CEE and methyl parathion (MP) were adsorbed in $60 \mathrm{~F}_{254}$ silica gel (Merck) in a rotatory evaporator with reduced pressure for complete homogenization with total removal of the solvents, which were ethanol for the extract of chinaberry and dichloromethane (DCM) for methyl parathion. In $200 \mathrm{~g}$ of silica gel, $27.67 \mathrm{~g}$ of CEE and $89 \mu \mathrm{L}$ of MP were adsorbed.

\section{Chromatographic analysis and isolation of compounds}

The phytochemical screening was done as described in literature (Yunes \& Calixto, 2001). This analysis was conducted by observing colorimetric variation after the addition of specific reagents. The phytochemicals analyzed are terpenes, flavonoids, coumarins, alkaloids and tannins.

The CEE $(15 \mathrm{~g})$ was fractionated on chromatographic column over Silica gel 60 (Merck). The eluents of hexane $(\mathrm{Hx})$, dichloromethane (DCM), ethyl acetate (EA), and ethanol were used in a gradient of increasing polarity. By elution with DCM/AE (60/40) given $70 \mathrm{mg}$ of melianone and with DCM (100\%) given $40 \mathrm{mg}$ of linoleic acid, which were identified by spectroscopic data (IR, ${ }^{1} \mathrm{H}$ and ${ }^{13} \mathrm{C}$ NMR, MS) and compared with literature values (Lavie et al., 1967).

\section{Toxicity test of MP and CEE on odonata larvae}

In a previous study, Tomazelli et al. (2011) concluded that Neuraeschna larvae were present with the greatest frequency, classifying these larvae as the main predators of fingerlings among the odonatas in the fishponds used in their study; thus, this genus of larvae was used in toxicity tests.

The mortality tests were performed inside a room at a temperature of $230 \mathrm{C}$ with $12 / 12 \mathrm{~h}$ light and dark photoperiods. Polyethylene tanks were used with dimensions of $17 \mathrm{~cm}$ in length $\times 11.5 \mathrm{~cm}$ in width $\times 10$ $\mathrm{cm}$ in height, with a capacity of $1.0 \mathrm{~L}$. The tanks were installed on a bench and supplied with local water from a deep tube well. The tanks were prepared with 0.5 
$\mathrm{cm}$ of sand on the bottom, which had been sterilized at $121^{\circ} \mathrm{C}$ for an hour. The concentrations of the treatments were obtained by weighing the silica adsorbed from the MP and the CEE; these concentrations were subsequently applied over a substrate of sand with water. The efficiency of the use of silica at the bottom of the containers was tested with the MP sample first, which is an organophosphate widely used in fish farming to control insect larvae.

Odonata larvae, Neuraeschna (Aeshnidae), were collected from a nursery pond of fingerlings of common carp (Cyprinus carpio) and immediately taken to the laboratory in a container with water from the nursery pond where they were measured for length and total weight and then acclimated in the laboratory for a period of 24 hours prior to testing. To perform the tests, the individual larvae were separated and randomly distributed in the previously prepared tanks. They were then exposed to increasing concentrations of MP and CEE adsorbed in silica and to the control treatment, with five repetitions of each. The preliminary biological assays with MP were performed in concentrations of $5.0,2.0,1.0$, and $0.50 \mathrm{mg} \mathrm{L}^{-1}$ and the definitive biological assays used concentrations of $0.50,0.25,0.13$, and $0.06 \mathrm{mg} \mathrm{L}^{-1}$. For the CEE, the preliminary assays were performed with concentrations of 5.0, 2.0, and $1.0 \mathrm{mg} \mathrm{L}^{-1}$, and the definitive assays had concentrations of $2.0,1.0,0.5$, and $0.25 \mathrm{mg} \mathrm{L}^{-1}$.

The evaluations were performed at intervals of six hours after the beginning of the tests, registering the number of dead larvae in each treatment. The data of water temperature, the concentration of dissolved oxygen (DO), $\mathrm{pH}$, and electric conductivity were obtained during the evaluations with a digital oxygen meter, $\mathrm{pH}$ meter, and conductivity meter, respectively.

\section{Evaluation of the toxicity of CEE in fingerlings of common carp (Cyprinus carpio)}

The common carp (Cyprino carpio) fingerlings used in the toxicity tests were captured on a rural property that produces fingerlings obtained through induced reproduction. The fingerlings had been in a soil fishpond for fifteen days where they were fed plankton and balanced diet powder.

The tests were performed in a room at a temperature of $23^{\circ} \mathrm{C}$ and $12 / 12 \mathrm{~h}$ light and dark photoperiods. Polyethylene tanks with dimensions of $17 \mathrm{~cm}$ in length $x 11.5 \mathrm{~cm}$ in width $x 10 \mathrm{~cm}$ in height were used, with a capacity of $1.0 \mathrm{~L}$. The tanks were installed in a bench and supplied with water from a deep tube well. The tanks were prepared with $0.5 \mathrm{~cm}$ of sand on the bottom, which had been sterilized at $121^{\circ} \mathrm{C}$ for an hour. After obtaining the measurements of length and total weight, three fingerlings were randomly placed in each tank. The tanks had been previously prepared and exposed to increasing concentrations adsorbed in silica of 2.0, 1.0, 0.50 , and $0.25 \mathrm{mg} \mathrm{L}^{-1}$ in addition to the control treatment, with five repetitions.

The evaluations were performed at intervals of six hours after the beginning of the tests, registering the number of live fingerlings in each treatment. The data of water temperature, the concentration of dissolved oxygen (DO), $\mathrm{pH}$, and electric conductivity were obtained during the evaluations, with a digital oxygen meter, $\mathrm{pH}$ meter, and conductivity meter, respectively.

\section{Statistical analysis}

All results represent the means of five replicates. Regression analysis and lethal concentration $\left(\mathrm{LC}_{50}\right)$ were performed using $\mathrm{R}$ ( $\mathrm{R}$ Development Core Team 2014) and the add-on package'nls'.

\section{RESULTS}

\section{Phytochemical screening}

In the phytochemical analysis, the fractions of $\mathrm{Hx}, \mathrm{DCM}, \mathrm{EA}$, and ethanol showed positive results for terpenes and steroids. The fractions of DCM, EA, and ethanol also showed positive results for coumarins when screened with UV rays. None of the fractions had positive results for flavonoids when tested with $3 \%$ iron (III) chloride $\left(\mathrm{FeCl}_{3}\right)$. For alkaloids, there was a positive result in the fraction of EA when screened with a Dragendorff solution. There was no evidence of tannins in any of the fractions (Table 1).

Table 1 - Phytochemical screening of CEE by TLC.

\begin{tabular}{lccccc}
\hline & Terpenes & Flavonoids & Coumarins & Alkcaloids & Tannins \\
\hline $\mathrm{Hx}$ & + & - & - & - & - \\
$\mathrm{EA}$ & + & - & + & + & - \\
$\mathrm{DCM}$ & + & - & + & - & - \\
Ethanol & + & - & + & - & - \\
\hline \multicolumn{2}{r}{ +present; - absent } & & &
\end{tabular}

Two compounds, linoleic acid and melianone, were isolated and identified from CEE. The latter is a member of the proto-limonoids, which are considered biogenetic precursors of limonoids (Polonsky et. al., 1977); its chemical structure, tetracyclic triterpene, was isolated and identified by Lavie et al. (1967) from extracts from Melia azedarach fruits.

\section{Toxicity test of MP on Neuraeschna larvae}

In the preliminary tests, the highest concentration tested was 10 times the concentration indicated for direct use in water, and the lowest concentration coincided with the concentration indicated by Woynarovich \& Horvath (1981) and Garadi (1988). After 6 hours of exposure, there were mortalities at concentrations of 
$5.0 \mathrm{mg} \mathrm{L}^{-1}$ and $2.0 \mathrm{mg} \mathrm{L}^{-1}$ of two larvae and one larva, respectively. The first treatment with total mortality was the concentration of $5.0 \mathrm{mg} \mathrm{L}^{-1}$ after 12 hours of exposure, when the mortalities began with the treatments of 2.0 and $0.5 \mathrm{mg} \mathrm{L}^{-1}$. At 18 hours, the two treatments with the greatest concentrations presented total larval mortality, whereas the concentrations of 1.0 and $0.5 \mathrm{mg} \mathrm{L}^{-1}$ had mortalities of $80 \%$. The experiment was concluded after 24 hours with total mortality in all of the treatments except for the concentration of 1.0 $\mathrm{mg} \mathrm{L}^{-1}$, with one surviving larva, which nonetheless did not react when stimulated with predation.

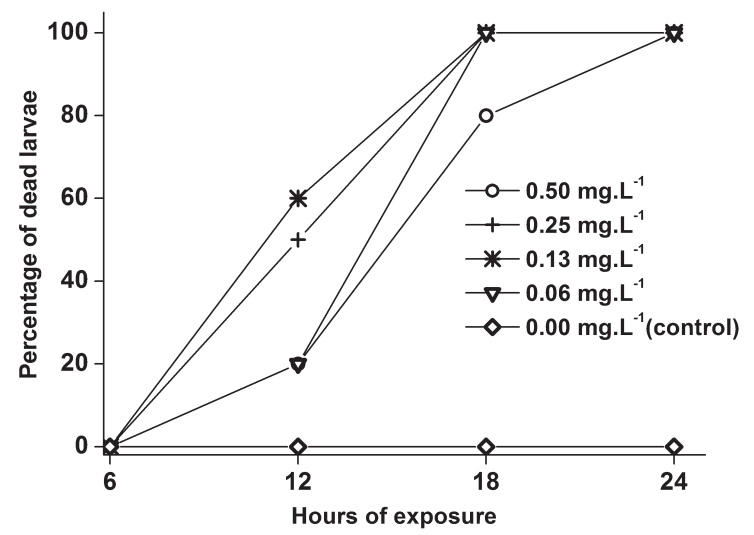

Figure 1 - Neuraeschna mortality exposed to increasing concentrations of MP adsorbed in silica and to the control treatment.

\section{Evaluation of the control of Neuraeschna larvae with CEE}

By adsorbing the EEC in silica occurs decanting since it is denser than water and release the extract or the insecticide in the bottom of the tank where are the odonata larvae. In the preliminary tests, at 12 hours of exposure to the treatments of 5.0 and $2.0 \mathrm{mg} \mathrm{L}^{-1}$, the first mortalities occurred. At 18 hours in the $5.0 \mathrm{mg} \mathrm{L}^{-1}$ treatment, there was $60 \%$ mortality, and in the 2.0 and $1.0 \mathrm{mg} \mathrm{L}^{-1}$ treatments, the mortality was $80 \%$. The $2.0 \mathrm{mg} \mathrm{L}^{-1}$ treatment presented a mortality of all larvae after 24 hours of the test, and the $5.0 \mathrm{mg} \mathrm{L}^{-1}$ and $1.0 \mathrm{mg} \mathrm{L}^{-1}$ treatments had mortalities of $80 \%$. The test conducted after 36 hours of exposure to CEE had $100 \%$ mortality in the 2.0 and $1.0 \mathrm{mg} \mathrm{L}^{-1}$ treatments. In the $5.0 \mathrm{mg} \mathrm{L}^{-1}$ treatment, one larva remained alive, but it presented no reaction to predation.

In an attempt to find the minimum lethal concentration, the biological tests were performed with four more treatments of 2.0, 1.0, 0.50 , and $0.25 \mathrm{mg} \mathrm{L}^{-1}$.

In the definitive test, the treatment of $2.0 \mathrm{mg} \mathrm{L}^{-1}$ was consistent with the preliminary test, with mortality beginning after 12 hours of exposure, whereas mortality began at 18 hours in the other treatments. After 24 hours, all larvae were dead in the 2.0 and
$0.5 \mathrm{mg} \mathrm{L}^{-1}$ treatments, with $80 \%$ and $40 \%$ in the 1.0 and $0.25 \mathrm{mg} \mathrm{L}^{-1}$ treatments, respectively. At 30 hours of exposure in the treatment with the lowest concentration, $0.25 \mathrm{mg} \mathrm{L}^{-1}, 60 \%$ of the larvae were dead, which was maintained until a time of 36 hours, when the test was concluded; the remaining larvae at that time presented slow movements with no reaction when stimulated with food (Fig. 2). At the end of the experiment, the control treatment larvae exhibited normal movement and reflexes. The Table 2 shows the values for the linear equations, $R^{2}$, and lethal concentration $\left(\mathrm{LC}_{50}\right)\left(\mathrm{mg} \mathrm{L}^{-1}\right)$ of MP and CEE for Neuraeschna larvae.

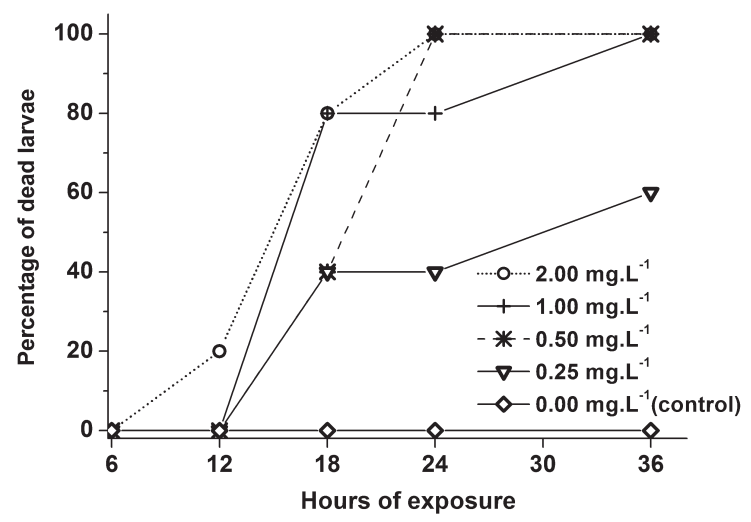

Figure 2 - Neuraeschna mortality exposed to increasing concentrations of CEE adsorbed in silica and to the control treatment.

Table 2 - Linear equations, R2 and lethal concentration $\left(\mathrm{LC}_{50}\right)\left(\mathrm{mg} \mathrm{L}^{-1}\right)$ of MP and CEE for Neuraeschna larvae.

\begin{tabular}{cccc}
\hline & Linear Equation & $\mathrm{R}$ & $\begin{array}{c}\mathrm{LC} \\
(\mathrm{mg} \mathrm{L}-1)\end{array}$ \\
\hline $\begin{array}{c}\text { Metyl Parathion } \\
12 \mathrm{~h}\end{array}$ & $\mathrm{y}=248.5 \mathrm{x}+7.66$ & 0.943 & 0.17 \\
$\begin{array}{c}\text { Ethanolic extract of Melia } \\
\text { Azedarach (CEE) } \\
18 \mathrm{~h}\end{array}$ & $\mathrm{y}=248.56 \mathrm{x}+7.66$ & 0.943 & 0.57 \\
$24 \mathrm{~h}$ & $\mathrm{y}=323.10 \mathrm{x}+19.39$ & 0.883 & 0.37 \\
$30 \mathrm{~h}$ & $\mathrm{y}=375.72 \mathrm{x}+23.67$ & 0.922 & 0.27 \\
$36 \mathrm{~h}$ & $\mathrm{y}=375.72 \mathrm{x}+23.67$ & 0.922 & 0.27 \\
\hline
\end{tabular}

\section{Evaluation of the toxicity of CEE among fingerlings of common carp (Cyprinus carpio)}

During the 36 hours of the tests with fingerlings of common carp (Cyprinus carpio) exposed to treatments of $2.0,1.0,0.5$, and $0.25 \mathrm{mg} \mathrm{L}^{-1}$ of CEE adsorbed in silica, there was no mortality. The mobility and reflexes of these fingerlings remained unaltered when compared to the control treatment (without CEE).

\section{DISCUSSION}

\section{Phytochemical screening}

According to Rana (2008) and Ntalli et al. (2010), meliantriol and melianone are the main compounds 
present in the fruits of the Melia genus, although cinnamoylmelianolone and melianol are also present.

Su et al. (1990), evaluating the phage-inhibiting compounds for the fruit of Phellodendron chinese with action against Reticulitermes speratus, demonstrated phage inhibition activity for melianone in a concentration of $100 \mu \mathrm{g} / \mathrm{disk}$ with a higher intensity at high doses (1000 $\mu \mathrm{g} / \mathrm{disk})$.

\section{Toxicity test of MP on Neuraeschna larvae}

Methyl parathion is a potent acetylcholinesterase inhibitor with a profound effect on the nervous system of exposed organisms, causing continuous excitation and leading to paralysis (Edwards \& Thounwou, 2005; Santos, 2007). Organophosphate insecticides are used generally in fish farming by directly applying them to water to control for odonatas and external parasites. The most widely applied recommendation for control of odonata larvae is $0.5 \mathrm{mg} \mathrm{L}^{-1}$ of MP, considering the total volume of water of the nursery fishponds for the calculation of the dilution (Woynarovich \& Horváth, 1981; Garadi, 1988; Tamassia, 1996). There is no study indicating the concentration of this organophosphate available for benthic insects that can be compared with this study.

With the incorporation of MP in silica, there was a reduction of a factor of 2.94 in the lethal dose in relation to the traditional technical indication for control of odonatas in fish farming. The most important result of this experiment was the effectiveness of this method in pest control, which can lead to using silica as a basis for the application of natural products (plant extracts) in substitution of synthetic pesticides.

There was no significant difference in the $F$ test $(p>0.05)$ among the physical-chemical variables of the water among the treatments (Table 3 ). The values were found to be within the range considered as ideal for fish farming (Boyd, 1990).

Table 3 - Total length of the Neuraeschna larvae exposed to increasing concentrations of MP adsorbed in silica, mean and standard deviation of physical-chemical variables of the water.

\begin{tabular}{cccccc}
\hline $\begin{array}{c}\text { Treatments } \\
(\mathrm{mg} \mathrm{L}-1)\end{array}$ & $\begin{array}{c}\text { Total lenght } \\
(\mathrm{cm})\end{array}$ & $\begin{array}{c}\text { Water } \\
\text { Temperature }\left({ }^{\circ} \mathrm{C}\right)\end{array}$ & $\begin{array}{c}\mathrm{DO} \\
\left(\mathrm{mg} \mathrm{L} \mathrm{L}^{-1}\right)\end{array}$ & $\mathrm{pH}$ & $\begin{array}{c}\text { Condutivity } \\
\left(\mu \mathrm{S} \mathrm{cm}{ }^{-1}\right)\end{array}$ \\
\hline 5.0 & $4.3 \pm 0.25$ & $23.54 \pm 1.03$ & $4.99 \pm 0.82$ & $7.71 \pm 0.80$ & 95.47 \\
& & & & & \pm 1.01 \\
2.0 & $4.3 \pm 0.26$ & $23.69 \pm .05$ & $4.95 \pm 0.8$ & $7.71 \pm 0.81$ & $95.53 \pm$ \\
& & & & & 0.92 \\
1.0 & $4.3 \pm 0.35$ & $23.69 \pm 1.04$ & $4.9 \pm 0.74$ & $7.72 \pm 0.78$ & $96.34 \pm 1.1$ \\
0.5 & $3.9 \pm 0.36$ & $23.62 \pm .87$ & $4.97 \pm 0.80$ & $7.73 \pm 0.76$ & $95.12 \pm 2.1$ \\
0.25 & $4.4 \pm 0.12$ & $23.50 \pm 1.10$ & $5.1 \pm 0.78$ & $7.99 \pm 0.84$ & $96.42 \pm 0.90$ \\
0.13 & $4.4 \pm 0.10$ & $23.55 \pm 1.00$ & $4.98 \pm 0.72$ & $7.72 \pm 0.79$ & $97.35 \pm 0.15$ \\
0.06 & $4.4 \pm 0.25$ & $23.60 \pm 1.02$ & $5.04 \pm 0.75$ & $7.73 \pm 0.82$ & $97.65 \pm 0.15$ \\
Control & $4.3 \pm 0.20$ & $23.40 \pm 0.90$ & $5.0 \pm 0.45$ & $7.70 \pm 0.82$ & $90.00 \pm 0.40$
\end{tabular}

\section{Evaluation of the control of Neuraeschna larvae with CEE}

Extracts from the fruits and leaves of Melia azedarach and of the Azadirachta indica neem have been studied to control insect pests in agronomic crops and in the control of fish parasites (Viegas, 2003; Cruz, 2005; Hammad \& Mcauslane, 2006; Scapinello et al., 2014a,b). Experiments performed with different concentrations of seed and leaf extracts of Melia azedarach have demonstrated the phage-inhibition activity and the negative effect on the development and survival of various species of insects that attack various agronomic crops (Carpinella et al., 2006), but no studies were found on the use of extracts of this plant for the control of aquatic insects.

In a study that evaluated the effect of the extract of Melia azedarach $\mathrm{L}$. on the predation of fingerlings of common carp (Cyprinus carpio) by Neuraeschna larvae, Tomazelli et al. (2011) concluded that the larvae of Odonata in the treatments with extract available at the bottom of the tanks presented a significantly lower consumption of fingerlings when compared to the treatments without extract application.

In contrast, the lethal concentration of MP and that found in this study justify the incorporation both of MP and of CEE in silica, as it allows the chemical compounds to be available closer to the target larvae, which is probably the explanation for having obtained a minimum lethal concentration 8 times lower than the concentration traditionally used in fish farming.

Similar to the MP treatment, there was no significant difference $(p>0.05)$ among the physical-chemical variables of the water among the treatments (Table 4). The values obtained were found to be within the range considered ideal for fish farming (Boyd, 1990).

Table 4 - Total length of the Neuraeschna larvae exposed to increasing concentrations of CEE adsorbed in silica, mean and standard deviation of physical-chemical variables of the water.

\begin{tabular}{cccccc}
\hline $\begin{array}{c}\text { Treatments } \\
\left(\mathrm{mg} \mathrm{L}^{-1}\right)\end{array}$ & $\begin{array}{c}\text { Total } \\
\text { lenght } \\
(\mathrm{cm})\end{array}$ & $\begin{array}{c}\text { Temperature } \\
\left({ }^{\circ} \mathrm{C}\right)\end{array}$ & $\begin{array}{c}\mathrm{DO} \\
\left(\mathrm{mg} \mathrm{L}^{-1}\right)\end{array}$ & $\mathrm{pH}$ & $\begin{array}{c}\text { Condutivity } \\
\left(\mu \mathrm{cm}^{-1}\right)\end{array}$ \\
\hline 5.0 & $4.5 \pm 0.10$ & $22.00 \pm 1.5$ & $4.9 \pm 0.8$ & $7.7 \pm 0.8$ & $120.89 \pm 7.7$ \\
2.0 & $4.4 \pm 0.05$ & $21.7 \pm 2.20$ & $5.1 \pm 0.6$ & $7.8 \pm 0.9$ & $130.01 \pm 7.8$ \\
1.0 & $4.6 \pm 0.20$ & $22.1 \pm 2.30$ & $5.2 \pm 0.5$ & $7.9 \pm 0.8$ & $129.90 \pm 9.82$ \\
0.5 & $4.4 \pm 0.10$ & $22.5 \pm 2.00$ & $4.8 \pm 0.7$ & $7.7 \pm 0.8$ & $121.35 \pm 7.31$ \\
0.25 & $4.5 \pm 0.150$ & $22.6 \pm 1.95$ & $5.0 \pm 0.4$ & $7.6 \pm 0.9$ & $111.50 \pm 1.76$ \\
Control & $4.4 \pm 0.120$ & $22.6 \pm 1.80$ & $5.0 \pm 0.7$ & $7.7 \pm 0.6$ & $114.90 \pm 0.7$ \\
\hline
\end{tabular}

\section{Evaluation of the toxicity of CEE among} fingerlings of common carp (Cyprinus carpio) CEE did not prove to be toxic in the concentrations and the period tested for common carp fingerlings. As before, there was no significant difference $(p>0.05)$ among the physical-chemical variables of 
the water among the treatments (Table 5). The values obtained were within the range considered ideal for fish farming (Boyd, 1990).

Table 5 - Total length of the Neuraeschna larvae, mean and standard deviation of physical chemical variables of the water during the CEE toxicity tests with common carp fingerlings.

\begin{tabular}{cccccc}
\hline $\begin{array}{c}\text { Treatments } \\
\left(\mathrm{mg} \mathrm{L}^{-1}\right)\end{array}$ & $\begin{array}{c}\text { Total } \\
\text { length }\end{array}$ & $\begin{array}{c}\text { Temperature } \\
\left({ }^{\circ} \mathrm{C}\right)\end{array}$ & $\begin{array}{c}\mathrm{DO} \\
\left(\mathrm{mg} \mathrm{L}^{-1}\right)\end{array}$ & $\mathrm{pH}$ & $\begin{array}{c}\text { Condutivity } \\
\left(\mu \mathrm{S} \mathrm{cm}^{-1}\right)\end{array}$ \\
\hline 10.00 & $4.5 \pm 0.1$ & $22.46 \pm 0.67$ & $6.64 \pm 1.31$ & $7.43 \pm 0.12$ & $79.3 \pm 2.9$ \\
& $4.4 \pm$ & & & & \\
5.00 & 0.05 & $22.50 \pm 0.65$ & $6.70 \pm 1.32$ & $7.46 \pm 0.15$ & $88.6 \pm 2.8$ \\
& & & & \\
2.5 & $4.6 \pm 0.2$ & $22.57 \pm 0.61$ & $6.84 \pm 1.07$ & $7.43 \pm 0.19$ & $88.4 \pm 2.63$ \\
1.25 & $4.4 \pm 0.10$ & $22.59 \pm 0.55$ & $7.00 \pm 0.88$ & $7.58 \pm 0.35$ & $87.7 \pm 3.3$ \\
0.5 & $4.5 \pm 0.15$ & $22.56 \pm 0.58$ & $6.81 \pm 1.05$ & $7.45 \pm 0.35$ & $88.0 \pm 3.3$ \\
Control & $4.4 \pm 0.12$ & $22.50 \pm 0.50$ & $6.74 \pm 0.65$ & $7.47 \pm 0.34$ & $88.1 \pm 2.8$
\end{tabular}

\section{CONCLUSIONS}

The absorption of MP into silica allowed us to determine a minimum lethal concentration for the odonata larvae, which was significantly different from the one used in fish farming.

The MP and CEE adsorbed in silica proved efficient in the control of odonata larvae, yet the onset of mortality was 12 hours later for the CEE treatment in relation to the MP tests and took 12 hours longer to reach completion.

The CEE demonstrated acute toxicity for the Neuraeschna larvae during the tests of predation, and it was not toxic to the common carp (Cyprinus carpio) fingerling at concentrations up to 7.4 times greater than the lowest lethal concentration calculated for Neuraeschna larvae.

For aquaculture to be responsibly developed, contributing to the improvement of the environment and guaranteeing the safety of the workers and of the general population, effective management and the development of "clean" technologies are necessary for the control of pests and diseases. In this context, the substitution of synthetic pesticides for natural products is a path that leads to the sustainability of fish farming. It is suggested that tests with odonatas continue in order to evaluate the biological activity of melianone and of the other semi-purified fractions of CEE.

\section{ACKNOWLEDGEMENTS}

This work was carried out with financial assistance from the Post Graduate Degree in Environmental Sciences of the Chapecó Region Community University - Brazil.

\section{REFERENCES}

Abutbul, S.; Golan-Goldhirsh, A.; Barazani, O.; Ofir, R. \& Zilberg, D. 2005. Screening of desert plants for use against bacterial pathogens in fish. J. Aquacult. - Bamidgeh. 57 (2): 71-80.

Ardó, L.; Yin, G.; Xu, P.; Váradi, L.; Szigeti, G.; Jeney, Z. \& Jeney, G., 2008. Chinese herbs (Astragalus membranaceus and Lonicera japonica) and boron enhance the non-specific immune response of nile tilapia (Oreochromis niloticus) and resistance against Aeromonas hydrophila. Aquaculture. 275 (1): 26-33.

Balasubramanian, G.; Sarathi, M.; Kumar, S. R. \& Hameed, A. S. S. 2007. Screening the antiviral activity of Indian medicinal plants against white spot syndrome virus in shrimp. Aquaculture. 263: 15-19.

Balasubramanian, G.; Srathia, M.; Venkatesan, C.; Thomas, J. \& Hameed, A.S.S. 2008. Oral administration of antiviral plant extract of Cynodon dactylon on a large scale production against white spot virus (WSSV) in Penaeus monodon. Aquaculture. 279: 2-5.

Boyd, C. E. 1990. Water quality in ponds for aquaculture. Birmigham Publishing, London, 482p.

Boyd, C. E. \& Massaut, L. 1999. Risk associated with the use of chemicals in pond aquaculture. Aquacult. Eng. 20: 113-132.

Carpinella, M. C.; Defagó, M. T.; Valladares, G. \& Palacios, S. M. 2006. Role of Melia azedarach L. (Meliaceae) for the control of insects and acari: present status and future prospects. In: Rai, M. \& Carpinella, M. (eds) Naturally occurring bioactive compounds. Advances in Phytomedicine. 3: 81-123.

Chakraborty S. \& Ghosh, U. 2014. In vivo immunological changes occurring at different time intervalsin white spot syndrome virus infected shrimp, treated with anti-WSSV drug derived from marine plants. Intl. J. of Basic \& Appl. Virol. 3(1): 01-15.

Claudiano, G.; Neto, J. D.; Sakabe, R.; Cruz, C.; Salvador, R. \& Pilarski, F. 2009. Eficácia do extrato aquoso de "Terminalia catappa" em juvenis de tambaqui parasitados por monogenéticos e protozoários. Rev. Bras. Saúde Prod. Anim. 10: 625-636.

Cruz, C. 2005. Aspectos toxicológicos de parathion metílico e de extrato aquoso de folhas secas de nim (Azadirachta indica) para o pacu (Piaractus mesopotamicus) e eficácia no controle de monogenea Dactylogyridae. Tese de Mestrado. Universidade Estadual Paulista - CAUNESP. 81p.

Edwards, F. L. \& Thounwou, P. B. 2005. Environmental toxicology and health effects associated with 
methyl parathion exposure - A Scientific Review. Int. J. Environ. Res. Public Health. 2: 430-441.

Eler, M. N.; Espíndola, E. L. G.; Espíndola, E. A.; Brigante, J.; Nogueira, M. M.; Nogueira, A. M. \& Milani, T. J. 2006. Avaliação da qualidade da água e sedimento dos pesque-pague: Análises físicas, químicas, biológicas e bioensaios de toxicidade. In: Eler, N. M. \& Espíndola, E. L. G., (eds.) Avaliação dos impactos de pesque-pague. Rima São Carlos. 101-144pp.

Garadi, P.; Domarco, R.C.; Araujo, O. J. \& PINHEIRO, C. W. L. 1988. Avaliação do uso de inseticidas (orgânicos fosforados) no combate às odonatas e na seleção zooplanctônica em piscicultura de alevinagem. 2a Edição. Estudos de piscicultura. Codevasf, Brasília, 71p.

Ghosh, U., Chakraborty S. \& Balasubramanian T., Das P. 2014. Screening, isolation and optimization of anti-white spot syndrome virus drug derived from terrestrial plants. Asian Pac. J. Trop. Biomed. 4(Suppl 1): S118-S128

Hammad, E. Abou-Fakhr \& Mcauslane, H. J. 2006. Effect of Melia azedarach extract on Bemisia argentifolii (Hemiptera: Aleyrodidae) and its biocontrol agent Eretmocerus rui (Hymenoptera: Aphelinidae). Environ Entomol. 35(3): 740-745.

Jain, G.; Pandit, D.; Gupta, P. \& Jharia, V. 2015. Evaluation of anti-inflammatory activity of seeds of Melia azedarach (Linn.) in albino wistar rats. IJSER. 6(1): 1837-1846.

Lavie, D.; Jain, M. K. \& Kirson, I. 1967. The complete structure of Melianone. J. Chem. Soc. C. 1347-1351.

Ntalli, N. G.; Cottiglia, F.; Bueno, C. A.; Alché, L. E.; Leonti, M.; Vargiu, S.; Bifulco, E.; MenkissogluSpiroudi, U. \& Caboni, P. 2010. Cytotoxic tirucallane triterpenoids from Melia azedarach fruits. Molecules. 15(9): 5866-5877.

Polonsky, J.; Varon, Z. \& Rabanal, R. M. 1977. 21,20Anhydromelianone and Melianone from Simarouba amara (Simaroubaceae); Carbon-13 NMR Spectral Analysis of 7- tirucallol-type Triterpenes. Isr. J. Chem. 16: 16-19.

Rana, V. AC. 2008. Plant review Melia azedarach: A phytopharmacological review. Pharmacog. Rev. 2: 173-178.

Rodrigues, E. L.; Ranzani-Paiva, M. J. T.; Pacheco, F. J.; Veiga, M. L. \& Eiras, A. C. 1997. Efeito agudo do organofosforado dipterex 500 (trichlorfon) em baço de curimbatá Prochilodus scrofa (STEINDACHNER, 1881). B. Inst. Pesca. 24: 197-203.

Rohana P. S.; Uwe B. \& Tacon A. 1996. Chemical in Asian Aquaculture: need, usage, issues and challenges. In: Arthur, J. R.; Lavilla-Pitogo, C. R. \& Subsainghe, R. P. (eds.) Use of chemicals in aquaculture in Ásia. Proceedings of the meeting on the use of chemicals in Aquaculture in Asia. Philippines, Tigbauan. 1-7pp.

Santos, N. D.; Costa, J. M. \& Pujol-Luz, J. R. 1988. Nota sobre ocorrência de odonatos em tanques de piscicultura e o problema de predação de alevinos pelas larvas. Acta Limnol. Brasil. 11: 771-780.

Santos, R. L. 2007. O uso de praguicidas nas atividades aquícolas: destino e efeito após aplicações em tanques experimentais e avaliação nas pisciculturas e pesqueiros da bacia do rio Mogi- Guaçu. Tese de Doutorado, Universidade de São Paulo - USP. 142p.

Scapinello, J.; Oliveira, J. V.; Chiaradia, L. A.; Tomazelli, O.; Niero, R. \& Dal Magro, J. 2014a. Insecticidal and growth inhibiting action of the supercritical extracts of Melia azedarach on Spodoptera frugiperda. R. Bras. Eng. Agríc. Ambiental. 18: 866-872.

Scapinello, J.; Oliveira, J. V.; Ribeiros, M. L.; Tomazelli, O.; Chiaradia, L. A. \& Dal Magro, J. 2014b. Effects of supercritical CO2 extracts of Melia azedarach L. on the control of fall armyworm (Spodoptera frugiperda). J. Supercrit. Fluid. 93: 20-26.

Schneider, P. R. 1987. Cultura do cinamomo. Fatec, Santa Maria: CEPEF/FATEC, 23p.

Su, R. H.; Takehiki, M. K. \& Takanashi, S. 1990. Antifeeding constituents of Phellondendron chinese fruit against Reticulitermes speratus. J. Pesticide Sci. 15: 567-572.

Tamassia, S. T. J. 1996. Carpa comum (Cyprinus carpio): produção de alevinos. EPAGRI Boletim Técnico no 76, Florianópolis, 40p.

Tomazelli Junior, O.; Munarini, A. C.; Casaca, J. M.; Franco, G. M. S. \& Dal Magro, J. 2011. Efeito do extrato de Melia azedarach sobre a predação de alevinos de carpa comum (Cyprinus carpio) por larvas de Neuraeschna (ODONATA: AESHNIDAE). Brazi. J. Aquat. Sci. Technol. 15(1): 19-25.

Viegas Junior, C. 2003. Terpenos com atividade inseticida: Uma alternativa pra o controle químico de insetos. Quim. Nova. 26(3): 390-400.

Woynarovich, E. \& Horváth, L. 1981. Propagacion artificial de peces de aguas templadas: Manual para extencionistas. FAO, Rome. 187p.

Xiang X. \& Zhou X. H. 2000. Application effect of Chinese herb medicine to aquatic animal feeds. Cereal Feed Ind. 3: 27-29.

Yunes, R. A. \& Calixto, J. B. 2001 Plantas medicinais sob a ótica da química medicinal moderna. Argos, Chapecó, 523p.

aniboni Filho, E. 2000. Larvicultura de peixes de água doce. Informe agropecuário. Belo Horizonte. 21(203): 69-77.

Zanuzzo, F. S. 2010. Uso da Aloe vera L. no manejo 
Tomazelli, O.Jr., et al. (2016). Control of fingerlings predators by herbal extract.

de matrinchã (Brycon amazonicus). Tese de Mestrado, Universidade Estadual Paulista CAUNESP. 86p.

Submetido: Abril/2013

Revisado: Novembro/2015

Aceito: Dezembro/2015 